\title{
Thailand faces dilemma over bird flu vaccine
}

David Cyranoski, Tokyo

As Thailand's battle with avian influenza drags on, the government has started to crack down on the illegal use of bird vaccines, with several high-profile arrests last month. But farmers are thought to be relying on black-market vaccines in a desperate attempt to avoid culling their chickens, leaving the country debating whether vaccination should be allowed.

For Thailand, once one of the world's major poultry exporters, the outlook is bleak. More than 300,000 chickens have been destroyed since July, and the bird flu that began this summer remains active in 25 villages.

To farmers trying to protect their livelihoods, vaccination seems like a good idea. It promises to keep healthy birds infection-free and to lessen symptoms in those already infected.

But the unregulated use of vaccines can do harm, says Wantanee Kalpravidh, consultant on avian flu for the United Nations Food and Agriculture Organization in Bangkok. Vaccinated birds that seem healthy can still get infected and spread the virus. And in backyard farms, where chickens run around freely in close proximity to people and other animals, this can spell disaster, she says. "Farmers might not be aware of the risk. It's difficult to keep track of what's happening," she warns.

Black-market vaccines might also contain viruses that have not been properly inactivated, adds Ilaria Capua, who heads a World

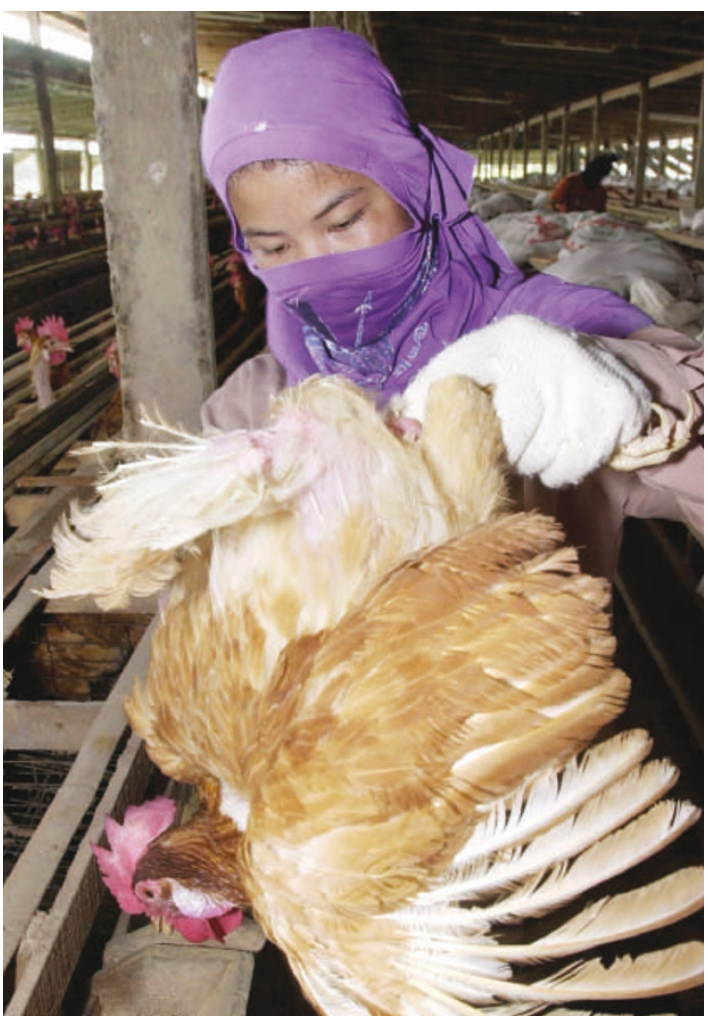

The Thai government insists that sick birds are culled.

Organization for Animal Health (OIE) laboratory in Padua, Italy. "You have no idea what you are buying," she says. The vaccine virus strain might also interact with any infectious flu strains present in the same bird, possibly leading to the evolution of a more dangerous virus. A long-term study of avian vaccines in Mexico has recently shown evidence of this
(C.-W. Lee, D. A. Senne and D. L. Suarez J. Virol. 78, 8372-8381;2004).

Culling is more straightforward and has proved effective - in developed countries at least. When a Texas chicken farm had outbreaks of avian flu in May and June this year, the area was isolated and all the chickens killed. By 25 August the United States was in the clear.

Experts note that vaccines can stop the spread of disease - if accompanied by strict monitoring and testing. This has been successful in parts of Italy and the United States. But many doubt that Thailand has the necessary resources.

Another strike against vaccines is economic, says Alex Thiermann, president of the OIE's Animal Health Code Commission in Paris. As long as a country is vaccinating, it will not get approval for export. This should change in May 2005, says Thiermann, when the rules are expected to become more flexible for developing countries such as Thailand, allowing them to continue trading when vaccinating safely.

Thailand is now deciding what to do. A technical committee reporting to the deputy prime minister is weighing the evidence for and against vaccination, says Kalpravidh. It is expected to reach a decision in the next few weeks.

In the meantime, police have raided market stalls that distribute vaccines to farmers, handing out heavy fines. An education campaign is also planned to explain the risks and benefits of vaccines. But experts doubt that this will stop the use of these vaccines entirely.

\section{Lab chiefs fear European rules will cost postdoc jobs}

\section{David Osumi-Sutherland, London}

British researchers are expressing concern

that European Union (EU) rules intended to give workers more job security could wreck the careers of postdocs in their labs.

The EU directive on fixed-term contracts became part of UK law in October 2002. According to Britain's research councils, it means that a postdoc must be offered a permanent contract after four years. In addition, lab chiefs must write a justification for not offering such a contract after three years. The first of these reviews will happen in October 2005.

But as lab chiefs face up to these requirements, they are complaining that they won't be able to increase the number of permanent contracts. The rules will force them to dismiss good postdocs, they say.

"If you are training group leaders they need to have publications. Three years is totally unrealistic, four is on the edge," says Alan Hall, head of the Medical Research Council's Laboratory for Molecular Cell Biology at University College London. "If it had been five then it might not have caused so many problems."

Mark Marsh, who runs an HIV lab at the MRC facility, says that he is worried about the effects on recruitment. "We have to tell potential postdocs that we can't guarantee more than 3-4 years," he says. "What if it takes $4 \frac{1}{2}$ years to get that crucial paper?"

The UK postdoc system - like that of the United States - has traditionally been very flexible. Contracts lasted as long as funding was available and the supervising researcher was happy with the work. But the system has been criticized for trapping postdocs in a series of short-term contracts, with no job security and little prospect of obtaining a permanent position.

Hall defends the old system. "The success of my research group depends on new young people coming to the group with new ideas and new directions," he says. He draws a distinct contrast with the situation in France, which he sees as a rigid system that depends mainly on permanent research staff.

The EU rules aren't specific to research, but were introduced as part of a general effort to push employers away from a reliance on short-term contracts. No one at the research commission in Brussels was available to comment on the rules' implications for science. But some unions that represent postdocs have argued for steps that would outlaw their indefinite retention on short-term contracts. 